\title{
Disallowance analysis through the audit of accounts performed by nurses: an integrative review
}

\author{
Análise de glosas por meio da auditoria de contas realizada por enfermeiros: revisão integrativa \\ Análisis de glosas por medio de la auditoría de cuentas realizadas por enfermeros: revisión integrativa
}

Universidade de São Paulo. São Paulo, São Paulo, Brazil.

How to cite this article:

Vigna CP, Ruiz PBO, Lima AFC. Disallowance analysis through the audit of accounts performed by nurses: an integrative review. Rev Bras Enferm. 2020;73(Suppl 5):e20190826. doi: http://dx.doi.org/10.1590/0034-7167-2019-0826

\section{Corresponding author: \\ Cinthia Prates Vigna \\ E-mail: cpvigna@gmail.com}

EDITOR IN CHIEF: Antonio José de Almeida Filho ASSOCIATE EDITOR: Hugo Fernandes

Submission: 03-16-2020
Approval: 06-26-2020

\begin{abstract}
Objective: Evidence the scientific production on the analysis of disallowances through the audit of accounts made by nurses. Method: Integrative literature review whose sample of ten articles was selected on the basis of The Cumulative Index to Nursing and Allied Health Literature, Latin American and Caribbean Literature in Health Sciences, EMBASE, Scielo, Web of science, Virtual Health Library and on the portal PubMed. Results: The ten articles obtained were published in Brazil, 80\% covering hospital contexts; with a quantitative (50\%), exploratory (40\%) and descriptive (60\%) approach. Studies investigating the occurrence of disallowance prevailed to identify the most impacting items on billing and possibilities for improvements in the process of auditing accounts by nurses. Conclusion: The verticalized knowledge of the disallowance analysis process is essential to identify non-conformities and propose improvements, aiming at assistance quality, adequate billing and consequent financial sustainability to health organizations.

Descriptors: Supplementary Health; Nursing Audit; Hospital Costs; Hospital administration; Revenues.
\end{abstract}

\section{RESUMO}

Objetivo: Evidenciar a produção científica sobre a análise de glosas por meio da auditoria de contas realizadas por enfermeiros. Método: Revisão integrativa da literatura cuja amostra de dez artigos foi selecionada nas bases The Cumulative Index to Nursing and Allied Health Literature, Literatura Latino-Americana e do Caribe em Ciências da Saúde, EMBASE, Scielo, Web of science, Biblioteca Virtual em Saúde e no portal PubMed. Resultados: Os dez artigos obtidos foram publicados no Brasil, $80 \%$ abrangendo contextos hospitalares; com abordagem quantitativa (50\%), do tipo exploratório (40\%) e descritivo (60\%). Prevaleceram estudos investigando a ocorrência de glosas para identificar os itens mais impactantes no faturamento e possibilidades de melhorias no processo de auditoria de contas por enfermeiros. Conclusão: $O$ conhecimento verticalizado do processo de análise de glosas é essencial para identificar não conformidades e propor melhorias, objetivando a qualidade assistencial, adequado faturamento e consequente sustentabilidade financeira às organizações de saúde. Descritores: Saúde Suplementar; Auditoria de Enfermagem; Custos Hospitalares; Administração Hospitalar; Faturamento.

\section{RESUMEN}

Objetivo: Evidenciar la producción científica sobre el análisis de glosas por medio de la auditoría de cuentas realizadas por enfermeros. Método: Revisión integrativa de la literatura cuya muestra de diez artículos ha sido seleccionada en las bases The Cumulative Index to Nursing and Allied Health Literature, Literatura Latinoamericana y de Caribe en Ciencias de la Salud, EMBASE, Scielo, Web of science, Biblioteca Virtual en Salud y en el portal PubMed. Resultados: Los diez artículos obtenidos han sido publicados en Brasil, $80 \%$ abarcando contextos hospitalarios; con abordaje cuantitativo (50\%), del tipo exploratorio $(40 \%)$ y descriptivo (60\%). Prevalecieron estudios investigando la ocurrencia de glosas para identificar los ítems más impactantes en la facturación y posibilidades de mejorías en el proceso de auditoría de cuentas por enfermeros. Conclusión: El conocimiento verticalizado del proceso de análisis de glosas es esencial para identificar no conformidades y proponer mejorías, objetivando la calidad asistencial, adecuada facturación y consecuente sustentabilidad financiera a las organizaciones de salud.

Descriptores: Salud Suplementaria; Auditoria de Enfermería; Costos Hospitalarios; Administración Hospitalario; Facturación. 


\section{INTRODUCTION}

For managers who aim at the sustainability of health organizations, making the efficient use of resources compatible with the quality of the services provided, cost reduction has become a major challenge in the face of the economic scenario and technological advances. The public sector has focused its concerns on assistance financing, raising taxes and pension reform; and the private sector handles the resulting increase in the costs of actions imposed both by the National Health Agency (NHA) for the regulation of the sector and by the increase in assistance costs ${ }^{(1)}$.

In view of this situation, especially considering the complexity of health organizations, the audit was configured as a tool to increase the quality of care and, in turn, costs, through the improvement of processes, enhancing the appropriate use of available resources and achieving the expected results ${ }^{(2)}$. According to the Institute for Healthcare Improvement, the strategic objectives for improving health systems include: improving the patient's experience in relation to care; improve the health of the population and reduce the per capita cost of health care ${ }^{(3)}$.

The audit of hospital accounts provides elements to act in the control of costs, as well as in the conference and in the control of the billing sent to Health Plan Operators; verification of tests and procedures performed; monitoring inpatients; and in structuring training for the areas involved. Specifically in the financial dimension, it favors the assessment of the billing process until the payment is completed and the monitoring of the organization's operational indicators ${ }^{(4)}$.

In hospitals, the growing role of nurses in the hospital billing process stands out, through the auditing of accounts, analyzing the documentation of the services provided to obtain the correct remuneration by the paying sources. In addition, the nurse has the potential to act in an educative way in the health team in order to reduce disallowances and, consequently, favor the achievement of better financial results ${ }^{(5)}$. Research carried out in a general hospital in the interior of Rio Grande do Sul found that investment in the daily educational process, based on the implementation of concurrent auditing, helped raise the awareness of professionals regarding the importance of auditing, alerting them to the impact of good practices to minimize financial losses ${ }^{(6)}$.

The disallowance of hospital accounts refers to the partial or total cancellation of the payment, being identified by the auditor at the time of the analysis when non-compliance is found. This practice, which is routine among the auditors, has repercussions on financial and relationship problems between the parties involved (health service providers and the source of payment), and the nurse auditor is responsible for managing this process ${ }^{(7)}$.

In view of the challenging changes that health systems are going through, whose processes need to consider both the quality and the value of the services provided, nurse auditors can act in the management of resources contributing to the balance between the increase in costs and the improvement of financial results from billing. However, it is inferred that the production of knowledge about disallowance analysis through the nursing audit is still small, indicating the relevance of conducting new studies. Thus, understanding the current state of the art on the scientific production of this theme motivated the realization of this study.

\section{OBJECTIVE}

Evidence the scientific production on the analysis of disallowances through the audit of accounts performed by nurses.

\section{METHODS}

This is an integrative review ${ }^{(8)}$ carried out with the required methodological rigor, following the following steps ${ }^{(9)}$ : identification of the theme and elaboration of the research question; establishment of criteria for inclusion and search for studies in the literature; definition of the information to be extracted from the selected studies; evaluation of the sample component studies; interpretation of results and presentation of the contents/ knowledge synthesis.

It was conducted with the purpose of answering the guiding question: "In view of the financial complexity involving health systems and the need to act with an emphasis on quality and rationalization of costs, what is the scientific production on the analysis of disallowances through the audit of accounts performed by nurses?"

For that, the PICO strategy was used, acronym for Patient, Intervention, Comparison and Outcomes (outcome), being: " $\mathrm{P}$ " - health institutions submitted to accounts audit; "I" - analysis of disallowances through the audit of accounts performed by nurses; " $C$ " - no intervention for comparison was established; and " $\mathrm{O}$ " - production on the analysis of disallowances through audit of accounts ${ }^{(10)}$.

Searches were performed in the electronic databases Web of Science, Latin American and Caribbean Literature in Health Sciences (LILACS), The Cumulative Index to Nursing and Allied Health Literature (CINAHL), EMBASE, SciELO, Virtual Health Library (VHL); and on the PubMed portal, which includes MEDLINE. The descriptors "Nursing audit", "Billing", "cost and cost analysis", "hospital costs" were selected from terms indexed in the Health Sciences Descriptors (DeCs) and Medical Subject Headings (MeSH terms) vocabularies.

The inclusion criteria were: articles published in Portuguese, English and Spanish, fully available, over a ten-year period (2009 to 2019), whose methodology evidenced the analysis of disallowances through the audit of hospital accounts performed by nurses. As directed by a librarian, two researchers independently searched the databases and portal mentioned above, with consensus being established through the inclusion criteria.

To detail the information collected from the articles, an instrument was used containing: identification of the original article (title, journal, year of publication); goals); methodological characteristics; local; data collection process; type of costing; main results; conclusions and identification of limitations and / or biases.

The details of the process of identification, selection, eligibility and inclusion of articles, according to the PRISMA recommendations ${ }^{(11)}$, is shown in Figure 1.

For the analysis and synthesis of the articles, two synoptic tables were used: one containing title, year and country; and another with objectives, design, outcomes and recommendations / conclusions. 


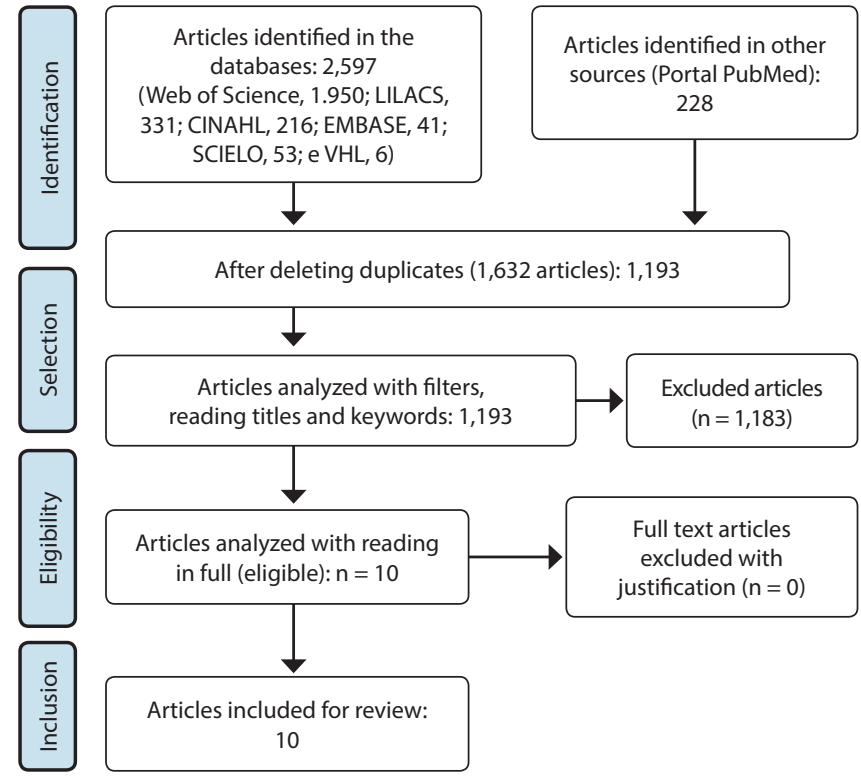

Figure 1 - Flowchart of identification, selection, eligibility and inclusion of studies following the PRISMA recommendations ${ }^{(11)}$, São Paulo, São Paulo, Brazil, 2019

\section{RESULTS}

As shown in Chart 1, 10 (100\%) articles ${ }^{(1,6,12-19)}$ comprised the sample of this integrative review. All of them were published in Brazil, with no publication related to the years 2019, 2016, 2013 and 2010 being found. It highlights the diversity of the study sites: private, public hospitals and Health Plan Operators.

It can be seen, in Chart 2, that all articles presented clear, concise and well-defined objectives, aiming to identify / analyze aspects covering the analysis of accounts, disallowances, nursing records, and the creation of an application to support the auditor in the process account analysis. Most of the analyzed publications originated from quantitative (50\%), exploratory (40\%), descriptive $(60 \%)$ studies, carried out in hospital contexts (90\%).

\section{DISCUSSION}

In recent studies ${ }^{(14-15)}$, the use of the "case study" modality was found, which consists of a systematic, in-depth analysis, which makes it possible to achieve an expanded understanding of the unique phenomena and situations of a given context and of those inserted in it ${ }^{(20)}$. Among the main contributions of the articles that made up the sample, the contribution of the audit process to improve disallowance management was highlighted; and the importance of developing indicators to enable improvements in the audit process of hospital bills, generating knowledge with the potential to improve healthcare billing.

The billing, in the hospital financial administration, translates into currency all operations to provide health care services. Thus, cost management in hospitals exceeds the needs related to the cost accounting cycle that ends with the application of the cost of products / services. In the billing process, evasions of operating revenues may be related to the non-collection of materials and drugs consumed; failure to charge for diagnostic support services; failure to meet the billing delivery deadlines; non-receipt of services provided due to disallowances and outdated procedure tables ${ }^{(21)}$

From this perspective, the audit of hospital accounts allows to verify the compatibility between the procedures performed and the collection of consumed items that are contractually established, between the service provider and the Health Plan Operators, considering the inputs used in the treatment of the patient (daily rates, administrative fees, medical fees, diagnostic services, materials, medicines, gases, among others) ${ }^{(22)}$.

Health institutions are complex and, therefore, the requirement for the involvement of health professionals in aspects of the accounting and financial area is understandable, with the purpose of adjusting costs and increasing resources through the business and marketing approach ${ }^{(23)}$. Therefore, in one of its dimensions, the audit can be used as a tool to control and regulate the use of health services, focusing, especially in the private area, on controlling the costs of the assistance provided ${ }^{(24)}$.

Chart 1 - Characterization of the articles included in the integrative review according to title, year and country, São Paulo, São Paulo, Brazil, 2019

\begin{tabular}{|c|c|c|}
\hline Title & Year & Country \\
\hline Disallowances in hospital accounts: a challenge to management ${ }^{(12)}$ & 2018 & Brazil \\
\hline Disallowances in hospital accounts: a challenge to management ${ }^{(13)}$ & 2018 & Brazil \\
\hline Audit and billing process in a private general hospital: a case study ${ }^{(14)}$ & 2017 & Brazil \\
\hline Implementation of competing nursing audit: an experience report ${ }^{(6)}$ & 2016 & Brazil \\
\hline Account audit study in a teaching hospital ${ }^{(15)}$ & 2015 & Brazil \\
\hline Disallowance of materials and medicines in a private hospital in the city of Brasília, Distrito Federal(1) & 2014 & Brazil \\
\hline Oncoaudit: application development and evaluation for nurse auditors ${ }^{(16)}$ & 2014 & Brazil \\
\hline Auditing in service providers: an economic management strategy ${ }^{(17)}$ & 2012 & Brazil \\
\hline The importance of nursing notes in hospital disallowances ${ }^{(18)}$ & 2011 & Brazil \\
\hline Nursing audit: the impact of nursing notes in the context of hospital disallowances ${ }^{(19)}$ & 2009 & Brazil \\
\hline
\end{tabular}


Chart 2 - Presentation of the objective, outline, outcomes and recommendations / conclusions of the articles included in the integrative review for the period from 2009 to 2018, São Paulo, Brazil, 2019

\begin{tabular}{|c|c|c|c|}
\hline Objective(s) & Outline & Outcomes & Recommendations / Conclusions \\
\hline $\begin{array}{l}\text { Analyze disallowances } \\
\text { made by a health plan } \\
\text { operator in hospital } \\
\text { accounts }^{(12)}\end{array}$ & $\begin{array}{l}\text { Quantitative, descriptive } \\
\text { and cross-sectional research. } \\
\text { Reports referring to } \\
\text { disallowances made in eight } \\
\text { hospitals in the operator's } \\
\text { accredited network were } \\
\text { analyzed, from } 2013 \text { to } 2015, \\
\text { totaling } 36 \text { thousand items. }\end{array}$ & $\begin{array}{l}\text { The highest disallowance rates occurred in } \\
\text { hospital } 1(67.6 \%) \text {; emergency room service } \\
\text { (50.1\%); length of stay } \leq 1 \text { day ( } 70.8 \%) \text { and } \\
\text { medical and hospital supplies }(59.2 \%) ; 2013 \\
\text { had the highest index of administrative } \\
(54.51 \%) \text { and technical disallowances } \\
(48.05 \%) \text {. }\end{array}$ & $\begin{array}{l}\text { Disallowances are indicators for } \\
\text { institutions to check the critical points } \\
\text { to be improved, requiring managers' } \\
\text { attention to intervene in the causative } \\
\text { aspects in order to prevent greater } \\
\text { losses. }\end{array}$ \\
\hline $\begin{array}{l}\text { Identify scientific } \\
\text { evidence available in the } \\
\text { literature that deals with } \\
\text { hospital disallowances } \\
\text { performed by the } \\
\text { nursing audit }{ }^{(13)}\end{array}$ & $\begin{array}{l}\text { Integrative review carried out } \\
\text { in the Scientific Electronic } \\
\text { Library Online databases; Latin } \\
\text { American and Caribbean Health } \\
\text { Sciences Information Literature. }\end{array}$ & $\begin{array}{l}\text { The role of the nurse auditor in the analysis } \\
\text { of procedures and care through professional } \\
\text { records, in reviewing disallowances and in } \\
\text { negotiations between hospital representatives } \\
\text { and of the agreement. The indicators } \\
\text { responsible for the largest number of } \\
\text { disallowances were related to nursing notes. }\end{array}$ & $\begin{array}{l}\text { The importance of complete and } \\
\text { objective nursing records in the clients' } \\
\text { medical records is highlighted, as it is } \\
\text { through them that the audit controls } \\
\text { financial costs and assesses the quality } \\
\text { of care provided. }\end{array}$ \\
\hline $\begin{array}{l}\text { Describe the experience } \\
\text { of nurses regarding } \\
\text { the implementation } \\
\text { of concurrent nursing } \\
\text { auditing in a hospital } \\
\text { environment }^{(6)}\end{array}$ & $\begin{array}{l}\text { Experience report on the stages } \\
\text { of the implementation process } \\
\text { of concurrent audit in hospital } \\
\text { from } 2009 \text { to 2014: elaboration } \\
\text { of the instrument, awareness } \\
\text { of the nursing team and } \\
\text { operationalization. }\end{array}$ & $\begin{array}{l}\text { The nurses indicated as benefits of the } \\
\text { concurrent audit: reduction of the time to } \\
\text { send the invoice to the medical plans; greater } \\
\text { interaction between auditors and assistance } \\
\text { teams; improving care quality and nursing } \\
\text { records. }\end{array}$ & $\begin{array}{l}\text { The nurse auditor must seek a balance } \\
\text { between the quality of nursing care } \\
\text { and the hospital cost. For this, you } \\
\text { must develop / adopt processes that } \\
\text { permeate the audit, amplifying your } \\
\text { results. }\end{array}$ \\
\hline $\begin{array}{l}\text { Map, describe and } \\
\text { validate the auditing } \\
\text { and billing process } \\
\text { of accounts and } \\
\text { disallowance resources in } \\
\text { a general, large, private } \\
\text { hospital }^{(14)}\end{array}$ & $\begin{array}{l}\text { Exploratory, descriptive, case } \\
\text { study research. The mapping of } \\
\text { the processes took place in the } \\
\text { Internal Audit and Disallowance } \\
\text { Sectors. The data obtained } \\
\text { was validated by specialists in } \\
\text { the field of audit of hospital } \\
\text { accounts, internal and external } \\
\text { to the hospital. }\end{array}$ & $\begin{array}{l}\text { The mapped processes - described and } \\
\text { illustrated in the form of three flowcharts - } \\
\text { favor professionals to rationalize activities } \\
\text { and time spent on hospital billing, avoiding } \\
\text { / minimizing the occurrence of failures and } \\
\text { generating more effective financial results. }\end{array}$ & $\begin{array}{l}\text { The mapping, detailed description and } \\
\text { validation of the auditing and billing } \\
\text { processes and disallowance by specialists } \\
\text { in the field of hospital accounts auditing, } \\
\text { give greater visibility and legitimacy to } \\
\text { the actions that are developed by the } \\
\text { nurse auditors and provide traceability } \\
\text { and systematic information retrieval with } \\
\text { greater reliability. }\end{array}$ \\
\hline $\begin{array}{l}\text { Check the items that } \\
\text { comprise hospital } \\
\text { bills, checked by nurse } \\
\text { auditors, who receive the } \\
\text { most adjustments at the } \\
\text { time of the pre-analysis; } \\
\text { identify the impact of } \\
\text { the adjustments in the } \\
\text { billing of the accounts } \\
\text { analyzed by nurses and } \\
\text { medical auditors; and } \\
\text { identify disallowances } \\
\text { related to items checked } \\
\text { by the audit team }\end{array}$ & $\begin{array}{l}\text { Quantitative, exploratory, } \\
\text { descriptive, single case study } \\
\text { type, in which } 2,613 \text { hospital } \\
\text { accounts were analyzed. }\end{array}$ & $\begin{array}{l}\text { The item most included by nurses was gases } \\
\text { (90.5\%); and the most excluded, inpatient } \\
\text { medications (41.2\%). Hemodynamic materials } \\
\text { (average R\$ 1,055.90), gases (average R\$ } \\
707.91 \text { ) and equipment (average R\$ } 689.42 \text { ) } \\
\text { were the ones that most impacted the positive } \\
\text { adjustments. The negative adjustments } \\
\text { resulted from improper entries in the accounts } \\
\text { and did not generate revenue losses. The items } \\
\text { that significantly influenced the disallowances } \\
\text { were the equipment, followed by hospital gas } \\
\text { and medication. In the accounts audited by } \\
\text { doctors, it was not possible to itemize the items } \\
\text { due to the absence of this record. }\end{array}$ & $\begin{array}{l}\text { The study provides data for the } \\
\text { advancement of knowledge of hospital } \\
\text { accounts auditing as it investigated the } \\
\text { pre-analysis process carried out by a } \\
\text { team of auditors consisting of nurses } \\
\text { and doctors. }\end{array}$ \\
\hline $\begin{array}{l}\text { Estimate the } \\
\text { disallowance rate on } \\
\text { materials and medicines } \\
\text { in a private hospital in } \\
\text { the Federal District }{ }^{(1)}\end{array}$ & $\begin{array}{l}\text { Quantitative, retrospective, } \\
\text { descriptive study. Data collection } \\
\text { took place in the billing } \\
\text { sector, based on disallowance } \\
\text { reports and semi-structured } \\
\text { questionnaire applied to } \\
\text { members of the sector. }\end{array}$ & $\begin{array}{l}\text { Materials have a higher level of disallowance } \\
\text { than drugs }(65 \%) \text {, and the impact of total } \\
\text { disallowances in the institution represented } \\
\text { approximately } 10 \% \text { of the billing of all } \\
\text { services. }\end{array}$ & $\begin{array}{l}\text { Disallowances may be reduced with } \\
\text { the adoption of service protocols by } \\
\text { health professionals involved in the } \\
\text { assistance process, providing cost } \\
\text { reduction and rational use of material } \\
\text { and medicines. }\end{array}$ \\
\hline $\begin{array}{l}\text { Develop chemotherapy } \\
\text { medication consultation } \\
\text { application for web } \\
\text { system and mobile } \\
\text { device in order to assist } \\
\text { in nursing audit of } \\
\text { hospital accounts and } \\
\text { assess user satisfaction } \\
\text { and usability }{ }^{(16)}\end{array}$ & $\begin{array}{l}\text { Applied research of } \\
\text { technological production aimed } \\
\text { at developing an application in } \\
\text { a web environment and mobile } \\
\text { technology for consultation } \\
\text { of chemotherapeutic drugs in } \\
\text { the audit of hospital accounts. } \\
\text { The product was evaluated for } \\
\text { satisfaction by nurse auditors } \\
\text { using the System Usability Scale } \\
\text { questionnaire and for usability } \\
\text { by Nielsen's heuristics, by health } \\
\text { informatics professionals. }\end{array}$ & $\begin{array}{l}\text { Five nurse auditors evaluated the application } \\
\text { on the tablet and five on the web system. The } \\
\text { evaluation with the System Usability Scale } \\
\text { questionnaire showed that the average value } \\
\text { was } 90 \pm 5 \text { for the application on the tablet and } \\
97 \pm 5 \text { on the web system. Nurses found the } \\
\text { application on the tablet easy to use, useful, } \\
\text { innovative, complete and with important } \\
\text { information to audit accounts of antineoplastic } \\
\text { drugs. } \\
\text { In the usability assessment, } 14 \text { problems were } \\
\text { identified in the mobile application and eight in } \\
\text { the web system, generating changes in both. }\end{array}$ & $\begin{array}{l}\text { The methods chosen for development } \\
\text { and evaluation proved to be } \\
\text { satisfactory to achieve the proposed } \\
\text { objectives. } \\
\text { Although with limitations due to the } \\
\text { small number of evaluators, it was } \\
\text { demonstrated that the application can } \\
\text { be used in the practice of medication } \\
\text { auditing, making it more agile and } \\
\text { complete. It may also achieve greater } \\
\text { repercussions with the incorporation } \\
\text { of more pharmacological groups. }\end{array}$ \\
\hline
\end{tabular}




\begin{tabular}{|c|c|c|c|}
\hline Objective(s) & Outline & Outcomes & Recommendations / Conclusions \\
\hline $\begin{array}{l}\text { Raise the reasons for } \\
\text { disallowed invoices, } \\
\text { forwarded to the } \\
\text { Commission of Lisura of } \\
\text { a military hospital in the } \\
\text { central region of the state } \\
\text { of Rio Grande do Sul(17) }\end{array}$ & $\begin{array}{l}\text { Quantitative, exploratory and } \\
\text { descriptive study. The sample } \\
\text { consisted of invoices belonging } \\
\text { to a specific health insurance } \\
\text { plan sent to the Commission } \\
\text { of Lisura of a military hospital } \\
\text { from January to June } 2007 \text {. }\end{array}$ & $\begin{array}{l}\text { It was shown that } 90 \% \text { of invoices had } \\
\text { inadequate and / or incomplete filling; } 30 \% \\
\text { had the charged medication (s) that did not } \\
\text { match the medical prescription, and } 40 \% \text { had } \\
\text { no medical progress on the visits charged. }\end{array}$ & $\begin{array}{l}\text { It was found that } 52.2 \% \text { of the audited } \\
\text { medical records had information } \\
\text { flaws that could result in total or } \\
\text { partial disallowance. The need to } \\
\text { adopt new training methodologies for } \\
\text { professionals to internalize their role in } \\
\text { health auditing has been proven. }\end{array}$ \\
\hline $\begin{array}{l}\text { Check in the national } \\
\text { literature the importance } \\
\text { and intervening factors } \\
\text { in nursing notes in } \\
\text { relation to hospital } \\
\text { disallowances }^{(18)}\end{array}$ & $\begin{array}{l}\text { Literature review with articles } \\
\text { published between } 2000 \text { and } \\
\text { 2010, in national scientific } \\
\text { journals available in the Virtual } \\
\text { Health Library, Scientific } \\
\text { Electronic Library Online, } \\
\text { Latin American and Caribbean } \\
\text { Literature in Health Sciences and } \\
\text { non-systematized sources. }\end{array}$ & $\begin{array}{l}\text { Twelve articles showed flaws in the nursing } \\
\text { notes: illegible handwriting, erasures, } \\
\text { inaccuracies regarding the time of the } \\
\text { annotation, identification of the professional, } \\
\text { checking of medicines, discrimination of } \\
\text { materials and annotation of the procedures } \\
\text { and the failure to implement the Nursing } \\
\text { Care Systematization. }\end{array}$ & $\begin{array}{l}\text { It is suggested the role of the nurse } \\
\text { auditor in supporting continuing } \\
\text { education teams and the use of } \\
\text { Nursing Care Systematization for } \\
\text { better qualification of nursing care, in } \\
\text { addition to reducing the number of } \\
\text { disallowances in hospital institutions. }\end{array}$ \\
\hline $\begin{array}{l}\text { Identify the impact caused } \\
\text { by the non-registration } \\
\text { of nursing as opposed } \\
\text { to any disallowances, } \\
\text { highlighting the main } \\
\text { types resulting from these } \\
\text { records }^{(19)}\end{array}$ & $\begin{array}{l}\text { Descriptive and exploratory } \\
\text { research, with a qualitative and } \\
\text { quantitative approach, carried } \\
\text { out in the urology service of a } \\
\text { private hospital in the city of } \\
\text { Niterói / Rio de Janeiro. }\end{array}$ & $\begin{array}{l}\text { 4,380 items were disallowed, highlighting, with } \\
\text { greater need, the following records: medications } \\
\text { (R\$ 8,551.07; } 53.16 \%) ; \text { oxygen ( } \$ \text { \$ 1,936.96; } \\
79.51 \%) ; \text { dressing (R\$ 1,008.52; } 41.40 \%) ; \\
\text { nebulization (R\$ 644.08; } 26.44 \%) ; \text { gauze pad (R\$ } \\
\text { 1,001.12; } 44.55 \%), \text { procedure glove (R\$ 869.62; } \\
38.70 \% \text { ) and lab coat (R\$ 656.76; } 29.22 \%) \text {. }\end{array}$ & $\begin{array}{l}\text { It is emphasized that nurses need } \\
\text { to assess the quality of the records } \\
\text { of nursing professionals under their } \\
\text { responsibility and plan educational } \\
\text { activities (systematic training) to improve } \\
\text { the training of these professionals in the } \\
\text { face of the flaws / inconsistencies found. }\end{array}$ \\
\hline
\end{tabular}

Some articles ${ }^{(6,12,15,18)}$, by analyzing the occurrence of disallowances and their impact on health care assistance billings, they found that the materials and medicines corresponded to the most representative items for being used directly in patient care.

In the hospital environment, the professionals responsible for the use of most consumable materials are nursing professionals, so they are responsible for the adequate management of these resources ${ }^{(1,4,25)}$. It is worth noting that hospital disallowances consist of the refusal to pay the invoice and or item of the hospital account analyzed by the Health Plan Operator's auditor, when he considers that the collection is undue according to the rules and practices of health institutions ${ }^{(18)}$.

A study ${ }^{(12)}$ performed at a Health Plans Operator, diagnosed the disallowances associated with different types of care (urgentemergency, surgical, clinical, obstetric, pediatric) and length of stay; and evidenced that this detail directs the audit process to the critical points, basing the managers in the adoption/implementation of improvement actions.

Article dealing with technological production of an application in a web environment aimed to facilitate the audit of hospital bills by nurses. It was indicated that the use of information and communication technology is a resource whose objective is to improve the performance of the nurse auditor by directing the best decision-making ${ }^{(16)}$. Other studies point to new perspectives for the performance of the audit, in the public and private sectors, using technology, among them the creation of automated models capable of identifying situations to be audited, directing to cases with greater chance of deviation and minimizing operational waste ${ }^{(26-27)}$.

One of the problems faced in carrying out the auditing of accounts is the non-conformity or absence of nursing notes in the medical records, which causes discrepancies in hospital charges, indicates possible failures in the care processes and infringes the ethical and legal aspects of this professional category. Literature review analyzed the main distortions and non-conformities that lead institutions to increase the number of disallowances and identified that it was related to the lack of nursing records. In this sense, it is necessary to develop an efficient account audit process, capable of linking the quality of care and hospital charges to the daily lives of nurse auditors ${ }^{(28)}$.

A study ${ }^{(15)}$ showed the repercussion of the performance of doctors and nurse auditors at the time of pre-analysis of accounts, checking all items related to patients from Health Plan Operators or private individuals, together with the respective medical records, in order to make corrections for systemic failures and prevent disallowances from occurring. Such an approach represents an advance in the audit models with a view to improving processes.

In addition to disallowance management, the mapping of processes has the purpose of increasing the management, organization and control of the required activities ${ }^{(19)}$. Only one study was identified $^{(14)}$ in which the authors mapped and described the auditing and billing processes of accounts and disallowance resources in a general, large, private hospital, which gave visibility to the actions developed by nurse auditors and provided the traceability and systematic retrieval of information. From this perspective, research carried out in a public university hospital has shown positive results after conducting an internal mapping of the accounts audit process - for example, reducing the time for presenting the accounts to Health Plan Operators ${ }^{(29)}$.

In view of the above, it is reiterated the importance of auditing accounts as a management strategy in hospitals and health plan operators that can provide conditions for the adequate receipt of the value of the health services provided, when duly explained and justified in the records in medical records, minimizing the occurrence of disallowances; it can also contribute to the reduction of waste of materials and medicines in healthcare practice.

In many institutions, the auditing of accounts carried out by nurses still has a strong accounting vision focused on the management of disallowances, however some investigations ${ }^{(14-19)}$ 
show the evolution of account auditing, focusing on identifying process failures, adjusting pre-analysis and mapping and validating processes. It is a change of operational performance for a strategic conception aiming to mitigate financial losses and, also, to improve the patient / client experience.

\section{Study limitations}

The reduced number of studies in the sample and the discontinuity in carrying out investigations in different contexts consisted of limiting aspects for the comparative analysis of the main results obtained.

\section{Contributions to the area of Nursing, Health or Public Policy}

The objectives, designs, outcomes and recommendations / conclusions of studies on the scientific production of the theme "audit of accounts performed by nurses" were synthesized, showing the advances and limitations of knowledge.

\section{CONCLUSION}

It was evident the prevalence of studies with an emphasis on the accounting view through the investigation of the occurrence of disallowances, however the beginning of the role of nurses in the use of auditing as a tool for improving internal processes in health institutions is seen

It is concluded that vertical knowledge of the disallowance analysis process is essential to identify non-conformities and propose improvements, seeking assistance quality, adequate billing and, consequently, financial sustainability for health organizations. The production of studies on disallowance analysis is still scarce. So, it is indicated the need for nurses to contribute to the production of knowledge about their qualified participation in the accounts audit process.

\section{REFERENCES}

1. Oliveira AD, Costa CR, Arndt ABM. Glosas de materiais e medicamentos em um hospital privado na cidade de Brasília, Distrito Federal. Acta Cienc Saude [Internet]. 2012 [cited 2019 May 21];2(1). Available from: http://www2.Is.edu.br/actacs/index.php/ACTA/article/view/39/46

2. Andrade AFSM, Benvides LNB. Custo efetividade da auditoria concorrente em uma operadora de saúde. Rev Adm Saúde [Internet]. 2019 [cited 2019 Nov 10];19(75):e162. Available from: http://cqh.org.br/ojs-2.4.8/index.php/ras/article/view/162/271

3. Berwick DM, Nolan TW, Whittington J. The triple aim: care, health, and cost. Health Aff (Millwood) [Internet]. 2008 [cited 2019 May 21];27(3):759-69. Available from: https://www.healthaffairs.org/doi/pdf/10.1377/hlthaff.27.3.759

4. Santos MP, Rosa CDP. Auditoria de contas hospitalares: análise dos principais motivos de glosas em uma instituição privada. Rev Fac Cienc Med Sorocaba [Internet]. 2013 [cited 2019 May 04];15(4):125-32. Available from: https://revistas.pucsp.br/RFCMS/article/view/17653/pdf

5. Dorne J, Hungare JV. Conhecimentos teóricos de auditoria em enfermagem. Rev UNINGÁ Rev [Internet]. 2013 [cited 2019 Nov 29];15(1):117. Available from: http://revista.uninga.br/index.php/uningareviews/article/view/738

6. Viana CD, Bragas LZT, Lazzari DD, Garcia CTF, Moura GMSS. Implementation of concurrent nursing audit: an experience report. Texto Contexto Enferm [Internet]. 2016 [cited 2019 May 29];25(1):e3250014. Available from: http://www.scielo.br/pdf/tce/v25n1/0104-0707-tce-25-01-3250014.pdf

7. Luz A, Martins AP, Dynewicz AM. Características de anotações de enfermagem encontradas em auditoria. Rev Eletrônica Enferm [Internet]. 2007 [cited 2019 May 21];9(2):344-61. Available from: https://revistas.ufg.br/fen/article/view/7165/5074

8. Mensik JS. Nursing's role and staffing in accountable care. Nurs Econ [Internet]. 2013[cited 2019 May 21];31(5):250-3. Available from: https:// europepmc.org/article/med/24294651

9. The Joanna Briggs Institute. Joanna Briggs Institute reviewers' manual: 2014 edition/supplement [Internet]. Adelaide: The Joanna Briggs Institute;2014 [cited 2018 Aug 12]. Available from: http://joannabriggs.org/assets/docs/sumari/reviewersmanual-2014.pdf

10. Souza MT, Silva MD, Carvalho R. Revisão integrativa: o que é e como fazer. Einstein [Internet]. 2010 [cited 2019 May 18];8(1):102-6. Available from: http://www.scielo.br/pdf/eins/v8n1/pt_1679-4508-eins-8-1-0102.pdf

11. Liberati A, Altman DG, Tetzlaff J, Mulrow C, Gøtzsche P, loannidis JPA, et al. The PRISMA statement for reporting systematic reviews and meta-analyses of studies that evaluate health care interventions: explanation and elaboration. PLoS Med [Internet]. 2009 [cited 2017 Sep 13];6(7):e1000100. Available from: https://journals.plos.org/plosmedicine/article/file?id=10.1371/journal.pmed.1000100\&type=printable

12. Rodrigues JARM, Cunha ICKO, Vannuchi MTO, Haddad MCFL Out-of-pocket payments in hospital bills: a challenge to management. Rev Bras Enferm [Internet]. 2018 [cited 2019 Jul 29];71(5):2511-8. Available from: http://www.scielo.br/pdf/reben/v71n5/0034-7167-reben-71-05-2511.pdf

13. Rodrigues JARM, Birolim MM, Cunha ICKO, Vannuchi MTO, Haddad MCFL. Hospital glosses in the nursing audit: an integrative review. Online Braz $j$ Nurs [Internet]. 2018 [cited 2019 Nov 19];17(1):150-60. Available from: http://www.objnursing. uff.br/index.php/nursing/article/view/5942

14. Zunta R, Lima A. Processo de auditoria e faturamento de contas em hospital geral privado: um estudo de caso. Rev Eletron Enferm [Internet]. $1^{\circ}$ de dezembro de 2017 [cited 2019 Nov 11];190. Available from: https://www.revistas.ufg.br/fen/article/view/42082

15. Guerrer GFF, Lima AFC, Castilho V. Estudo da auditoria de contas em um hospital de ensino. Rev Bras Enferm. 2015;68(3):414-20. Available from: doi: 10.1590/0034-7167.2015680306i

16. Grossi LM, Pisa IT, Marin HF. Oncoaudit: development and evaluation of an application for nurse auditors. Acta Paul Enferm [Internet]. 2014 [cited 2019 Nov 11];27(2):179-85. Available from: http://www.scielo.br/pdf/ape/v27n2/en_0103-2100-ape-27-02-0179.pdf 
17. Lana LD, Ferrazza CAC, Quadros JN, Birrer JA. Auditoria em organizações prestadoras de serviço: uma estratégia de gestão econômica. Rev Adm Saúde [Internet]. 2012 [cited 2019 Nov 11];14(56):103-8. Available from: https://cqh.org.br/portal/pag/anexos/baixar. php?p_ndoc $=420 \&$ p_nanexo $=343$

18. Prado PR, Assis WALM. A importância das anotações de enfermagem nas glosas hospitalares. CuidArte Enferm [Internet]. 2011 [cited 2019 Jul 14];5(1):62-8. Available from: http://www.fundacaopadrealbino.org.br/facfipa/ner/pdf/CuidArte\%20Enfermagem\%20v.\%205\%20n.\%20 1\%20jan.jun.\%202011.pdf

19. Ferreira TS, Souza-Braga AL, Cavalcanti-Valente GS, Souza DF, Carvalho-Alves EM. Auditoria de enfermagem: o impacto das anotações de enfermagem no contexto das glosas hospitalares. Aquichan [Internet]. 2009 [cited 2019 Sep 12];9(1):38-49. Available from: http://www. scielo.org.co/pdf/aqui/v9n1/v9n1a04.pdf

20. Yin RK. Case Study Research: Design and Methods. 5th ed. London: SAGE;2014

21. Mauriz C, Lobo F, Lima RR, Oliveira S, Medeiros G. Faturamento Hospitalar: um passo a mais. Rev Inova ação. [periódico na internet]. 2012 [cited 2019 Nov 11];1(1):38-44. Available from: http://www4.fsanet.com.br/revista/index.php/inovaacao/article/view/479

22. Scarparo AF, Ferraz CA, Chaves LDP. Auditoria como ferramenta de Avaliação dos Serviços de enfermagem. In: Vale EG, Lima JR, Felli VEA. (Org.). Programa de Atualização em Enfermagem (PROENF): Gestão. Porto Alegre: Artmed/Panamericana editora LTDA, 2011;1(1):91-121

23. Scarparo AF, Ferraz CA, Chaves LDP, Gabriel CS. Tendências da função do enfermeiro auditor no mercado em saúde. Texto Contexto Enferm. 2010;19(1):85-92. Available from: 10.1590/S0104-07072010000100010

24. Pinto KA, Melo CMM. A prática da enfermeira auditora em saúde. Rev Esc Enferm USP. 2010;44(3):671-8. doi: 10.1590/ S0080-62342010000300017

25. Dias TCL, Santos JLG, Cordenuzzi OCP, Prochnow AG. Auditoria em enfermagem: revisão sistemática da literatura. Rev Bras Enferm [Internet]. 2011 [cited 2019 Oct 14];64(5):931-37. Available from: http://www.scielo.br/pdf/reben/v64n5/a20v64n5.pdf

26. Araya AMP, Chupel JS, Carvalho DR, Dallagsa MR, loshii SO. Sistema inteligente para apoio em auditoria de contas médicas. J Health Inform [Internet]. 2016 [cited 2019 May 4];8(2):49-56. Available from: http://www.jhi-sbis.saude.ws/ojs-jhi/index.php/jhi-sbis/article/view/394

27. Assunção RM, Carvalho OSF, Prates MO, Campos MA. Anomaly detection in the sistema único de saúde payments. J Health Inform [Internet]. 2016 [cited 2019 Jul 29];8(Suppl I):459-68. Available from: http://docs.bvsalud.org/biblioref/2018/07/906376/anais_cbis_2016_artigos_ completos-459-468.pdf

28. Souza MSM, Fioravanti SGO, Colavolpe VC. Registro de enfermagem: desafio para as instituições hospitalares na redução de glosas. Rev Eletrôn Atualiza Saúde Salvador [Internet]. 2016 [cited 2019 Oct 14];3(3):84-91. Available from: http://atualizarevista.com.br/article/ registro-de-enfermagemdesafio-para-as-instituicoes-hospitalares-na-reducao-de-glosas-v-3-n-3/

29. Guerrer GFF, Castilho V, Lima AFC. Processo de formação de contas em um hospital de ensino especializado em cardiologia e pneumonia. Rev Eletron Enferm. 2014;16(3):558-65. doi: 10.5216/ree.v16i3.23487 